\title{
Türkiye'de Yerel Parti Örgütlenmesinde İki Farklı Model
}

\author{
Two Different Models of Local Party Organization in Turkey
}

Mehmet KABASAKAL ${ }^{1}$

Geliş tarihi: 28.06.2019, Kabul tarihi: 20.09.2019, Basım tarihi: 15.11.2019

\section{Öz}

Türkiye siyasetinde yerel örgütlenmenin partilerin seçim başarılarına katkısı, son yıllarda açık biçimde Milli Selamet Partisi, Refah Partisi ve Adalet ve Kalkınma Partisinde gözlenmiştir. Ancak, Türkiye'nin çok partili demokratik hayatında görülen ilk yerel örgütlenme 1946-60 arasında Türk siyasal yaşamına damgasını vuran "ocak ve bucak" örgütleridir. Bu çalışma, Türkiye'de 1946-60 arasında yasal biçimde örgütlenmiş formal ocak ve bucak teşkilatları ile 1970 sonrası bazı partilerde informal olarak oluşturulan yerel örgütlerin parti içi demokrasiye ve ülkede demokrasinin pekişmesine yaptığ katkıyı değerlendirmektedir. Çalışma, son yıllarda, 1950’lerin aksine, üyelerin veya yerel örgütlerin, partilerin karar mekanizmalarını etkileme gücünü büyük ölçüde yitirdiği savını ileri sürmektedir.

Anahtar sözcükler: Yerel parti örgütü, ocak-bucak örgütü, ocak örgütlerinin işlevi, siyasal katilma, parti içi demokrasi.

\begin{abstract}
Local party units made significant contributions to National Salvation Party, Welfare Party, and Justice and Development Party's success in the elections during the last decades. Although these three cases are informal structures which are quite well-known in the literature, Ocak-Bucak units were the first main formal local organizations which had a significant impact on political parties during the 1946-60 period. This paper analyzes the formal Ocak-Bucak organization of the 1946-60 period and the informal local organizations after 1970s by comparing their contributions to the intra-party democracy in Turkey, and also argues that the power of the local units and party members were significantly reduced in last decades.
\end{abstract}

Key words: local party organization, Ocak-Bucak units, functions of Ocak units, political participation, intra-party democracy.

\section{Giriş}

Dünyada siyasal partilerle ilgili çalışmalar daha çok seçimler, parlamento, hükümetler ve partilerin merkez organları üzerinde yoğunlaşmaktadır (Roscoe ve Jenkins, 2016:2). Oysa siyasal partilerin yerel örgütleri başta aday belirleme ve politika oluşturma olmak üzere birçok konuda partilerin merkez

\footnotetext{
${ }^{1}$ OKAN Üniversitesi, İşletme ve Yönetim Bilimleri Fakültesi, Dr. Öğretim Üyesi mehmet.kabasakal@okan.edu.tr https:// orcid.org/0000-0002-1097-6467
} 
yönetimlerine katkı sunarlar. Ayrıca, sivil toplumla, seçmenle birebir temas ederek partilerinin oylarını artırmalarını sağlarlar. $\mathrm{Bu}$ nedenlerle partilerin yerel örgütleri incelenmeye değer birimlerdir. Partilerin yerel düzeyde örgütlenmeleri, yasalara göre formal veya yasalarca öngörülmeyen informal biçimde olabilmektedir. Bu çalışma, özellikle çok partili yaşama geçişte etkin olan (formal) ocak-bucak örgütlenmesini ve yakın dönem (informal) parti yerel örgütlenmesi ile karşılaştırarak her iki modelin parti içi demokrasiye katkılarını sorgulamaktadır.

$\mathrm{Bu}$ makale, literatür taramasına, güncel akademik araştırmalara ve yazılara, biyografilere, gazete ve dergi yazılarına ve 1946-60 döneminde siyasal yaşama tanıklık etmiş farklı partilerden siyasetçi ve yazarlarla yapılan söyleşilere de dayanan betimleyici bir çalışmadır. Bu yazının amacı, hakkında fazla yayın ve araştırma bulunmayan, pek fazla da bilinmeyen ocak ve bucak örgütlerinin işleyişi hakkında siyaset bilimi yazınına yeni yayınlardan da yararlanarak katkıda bulunmaktır. Bu makalenin cevap aradığ1 soru yerel örgütlerdeki yapı ve işleyişin parti içi demokrasiyi ne ölçüde etkilediğidir. Bu çalışmanın savı, Türkiye'de 1946-60 arasında yerel örgütlerin parti içi demokrasiye ve ülkede demokrasinin pekişmesine yaptı̆̆1 katkının 1970 sonrası ortaya çıkan informal yerel örgütlemeyi kullanan partilerde görülmediğidir. Çalışma, yakın dönem yerel parti örgütlerinde, yerel örgütlerin partilerin karar mekanizmalarını etkileme gücünün ocak-bucak örgütlenmesine göre azaldığını ileri sürmektedir.

Araştırmacılar, dünyada partilerin yerel örgütlerinin 1970'li yıllardan itibaren geliştiğini ve parti içinde de güçlerini artırmaya başladıklarını belirtmektedirler (Cotter vd., 1984; Gibson, Frendreis ve Vertz, 1989). 1990'larda yapılan araştırmalar, partilerin yerel örgütlerinin güçlenmeyi sürdürdüklerini, özellikle seçim dönemlerinde daha da faal ve etkili olduklarını hatta siyasal sürecin ana aktörleri haline geldiklerine değinmektedirler (Frendreis ve Gitelson, 1999). Ancak, 1990'ların sonunda küresel gelişmeyle birlikte siyasal yaşamda pek çok şey değişmeye başlamış, örgütler de bu değişimi kavramaya, ögrenmeye ve değişime uyum sağlamaya çaba harcamışlardır (Appleton ve Ward, 1997; Beck ve Heidemann, 2014; Roscoe ve Jenkins, 2014). Medyanın ve elektronik iletişimin yaygınlaştı̆̆ bu ortamda yereldeki seçim kampanyaları tekrar kilit faaliyetler niteliği kazanmıştır.

Günümüzde siyasal partiler, güçlü finans yapılarına, istikrarlı örgütlere ve zengin insan kaynaklarına sahiptirler (Herrnson, 2002:54). 21. Yüzyılda partilerin, kamuoyu araştırmalarında, seçim kampanyası yönetiminde, aday belirlemedeki rolleri, parasal kaynak yaratma becerileri ve yerel etkinliklerde örgütsel başarı kapasiteleri artmıştır. Bu gelişmeler, partilerin finansal kaynaklarını, tanıtım imkanlarını, yeni üye kazanımlarını, eğitim çalışmalarını ve yerel faaliyetlerini daha da artırmalarını sağlamıştır (Aldrich, 2000). 
Bir toplumda sosyal hareketliliğin artması, siyasal katılma isteğini de artırır. Bir yurttaşın siyasete ve siyasal partilere ilgisini "katılma" olarak adlandırır isek, katılmanın dereceleri vardır. Duverger'e göre siyasete katılmanın, secmen, taraftar, ïye ve militan alarak tanımlanabilecek 4 farklı derecesi bulunmaktadır. Seçmen bir partiye ve adaylarına oy veren yurttaştır. Taraftar da bir seçmendir, fakat sadece seçmenden ibaret değildir; oy verdiği partiye sempatisini gizlemez, onu açıkça savunur, parasal destek verebilir ve partiye yakın örgütlere katılarak bu desteğini sürdürebilir. Bir partiye üye olmak, öncelikle giriş beyannamesini doldurup imzalamak demektir. Üyeler, partinin programını benimseyen, bir katılım formu doldurarak düzenli aidat ödeyen ve parti ile ilişkisini kurumsal olarak sürdüren taraftarlardır. Militanlar ise partinin aktif üyeleridir. Partilerin, militanlar olmaksızin parti etkinliklerini yürütmelerine imkan yoktur (1974:116, 138 ve 160-161).

Huntington, eğer bir ülkedeki siyasal kurumlar toplumun katılım talebini karşılayacak yapıda ve düzeyde değillerse o ülkede siyasal istikrarın sağlanmasının zor olacağını ileri sürmektedir (1977:55). Partilerin yerel örgütlerinde kurumsallaşma ve kurumsallaşma düzeyi bu süreçte büyük önem taşımaktadır. Bir örgütte kurumsallaşma, kurum kültürünün yönetimi, geliştirilmesi ve aktarılması kolay bir iş değildir. Siyasal kültür üzerine çalışmalarıyla tanınan ünlü siyaset bilimciler Gabriel A. Almond ve Sidney Vebra (1963), katılmacı siyasal sistemin demokratik biçiminin, onunla uyumlu bir siyasal kültür de gerektirdiğini ileri sürmektedirler. Siyasal partilerin kurumsal kültürü, sadece yasal düzenlemelerle biçimlendirilemez, partilerin kendi iç işleyişlerini şekillendiren kurallarla da yakından ilgilidir.

Parti içi işleyiş genel olarak yasal düzenlemeler ve tüzük kuralarına göre yürütülür. Partilere üyelik bireyin kendi tercihiyle gerçekleşir. Birçok parti başvuru sırasında iki üyenin de tavsiyesini gerekli görür. Kabul yetkisi genellikle partilerin yerel örgütlerindedir; talebin reddi halinde üst organlara başvurulabilir (Duverger, 1974:116-117; Kabasakal, 2014:707-708). Parti yönetiminde görev almak isteyen üyenin, partilerin niteliğine bağlı olarak, parti etkinliklerinde, toplantı ve mitinglerinde kendisini göstermesi beklenir.

Yerel örgütler ulusal düzeyde belirlenen politikaları yerel düzeyde hayata geçirmeye çalışılar. Ülkede yerleşik siyasal kültür, partilerdeki örgüt kültürü ve merkez organlarının uygulamaya koyduğu kurallar yerel örgütlerin biçimlenmesinde önemli rol oynar. Partilerin tarihsel geçmişi, toplumda benimsenme ve kökleşme düzeyi ile yöresel koşullar, yerel parti organlarının seçimlerde ne derece etkili olacağını belirleyen temel unsurlardır. Yani, ülkenin köklü partileri yöreyi iyi tanıyan yerel örgütleri kanalıyla daha etkili çalışmalar yapabilirler. 


\section{Yerel örgütlerin işlevleri}

Partilerin yerel örgütleri çeşitli işlevler görür ve etkinlikler gerçekleştirirler. Bu faaliyetlerin birçoğu seçim dönemlerinde partili adaylara destek olmak ve seçmenlere yönelik çalışmalar yapmakla ilgilidir (Clark, 2004; Tavits, 2013:61). Ancak, partilerin yerel birimlerinin yeni üye kazanma, üyelerin eğitimi, faaliyetlerin finansmanı gibi yaşamsal görevleri de vardır (Duverger, 1974:59, 74, 1001 ve 106). Partilerin yerel örgütleri yerel ihtiyaç ve sorunları derleyerek parti merkez organları ile seçmen arasında etkili bir iletişim sağlarlar. Ayrıca, parti program ve ideolojisinin gelişmesine katkıda bulunurlar. Parti tüzügü öngörüyor ise yerel adayları belirleyip, parti adaylarını seçimlere hazırlarlar. Araştırmalar, yerelde siyasal deneyim kazanan birçok adayın partilerinin genel seçimlerdeki başarısına katkıda bulunduğunu da göstermektedir. Yerel birimler, üyelerin parti aidiyet duygularının pekiştirilmesinde önemli roller oynarlar. Yerel örgütlerin siyasal katıllımı artırmaya yönelik faaliyetleri sadece seçmenin harekete geçirilmesine değil, potansiyel seçmenin taraftara dönüştürülmesine de katkı sağlar (Tavits, 2013:28-30). Partiler bu amaçla yerel düzeyde de eğitimler yapar, yayınlar ç1karırlar.

Partilerin yerel örgütleri, yörenin ve yöre halkının sorunlarını belirleyerek yerel düzeyde çözülebilecek sorunlara ilçe ve ilde, parti organları, belediyeler ve sivil toplum kuruluşları kanalıyla çözümler getirmeye çalışırlar. Yerel düzeyde çözülme imkanı bulunmayan, çözümleri yasal düzenleme gerektiren konular ise parti üst yönetimine yansitllır.

Tüm kurumlarda olduğu gibi, partilerin yerel örgütlerinde de üyelerin motivasyonu ve aidiyet duygusunun pekiştirilmesi önemlidir. Bazı üyeler yönetim kademelerinde yer alarak çevrelerinde ekonomik, toplumsal ve siyasal ilişkiler ağları kurarak parti içinde yükselmeyi amaçlarlar. Yönetim organlarında görev alıp bir sonraki örgüt seçimlerine kadar görevi yürüten bu yerel liderlerden farklı olarak; militan diye de tanımlanan aktif parti üyeleri, partinin tüm önemli etkinliklerinin çekirdeğini oluştururlar (Duverger, 1974: 160-161). Aktif üyeler özellikle seçim zamanlarındaki çalışmalarda öne çıkar ve kapı kapı dolaşarak seçmenlerle etkin bir ilişki içinde olmaktan haz alırlar. Gazeteci-yazar Orhan Bursalı'nın 24 Haziran 2018'de yapılan milletvekili seçimleriyle ilgili analizinde yer verdiği gözlemler, bu örgütlenme yönteminin seçim başarısına etkisini doğrular niteliktedir (2018:6).

Parti örgütünün gücü ve seçimlerdeki başarıs1, özellikle yerel düzeyde etkin olan üye sayısıyla yakından ilgilidir. Yereldeki parti faaliyetlerinin türü ne olursa olsun amaç seçimde partinin hedeflerine ulaşmasıdır. Bu etkinlikleri yönetenler de etkinliklere aktif olarak katılanlar da hedefe ulaşılınca çabalarının karşılığını bir ölçüde görürler. Bir göreve seçilmek gibi somut hedefler, parti yöneticilerinin motivasyonunda rol oynasa bile aktif üyeler için dayanışmayla sağlanan siyasal başarı, maddi yararlardan daha önce 
gelmektedir. Sade üyelerin önceliği, dayanışma içinde bir amaca erişmenin ve çevrelerinde takdir edilmenin hazzını tatmaktır. Parti yöneticilerini ve aktif üyeleri güdüleyen asıl itici unsur hedeflerin gerçekleştirilmesidir. Bu hedefler hem kurumsal değerleri, parti ilkelerini, hem de bireysel inançları kapsar ve onları örgütün amaç ve politikaları ile birleştirir (Roscoe ve Jenkins, 2016:103-106).

\section{Yerel örgütler ve parti içi demokrasi}

Çıkarları birleştirmek, yurttaşlarla devlet yönetimi arasında bağ kurmak, siyasal kadro yetiştirmek ve devletin siyasal karar organlarını yönetmek gibi işlevler yüklenen siyasal partilerin, demokratik sistemlerdeki rolü özellikle önemlidir (Kapani, 2005:165-168). Çünkü bu ülkelerde demokrasinin sağlıklı işlemesi, siyasal hayatın her türlü yasaktan arındırılmış olması yanında siyasal partilerin kendi içlerinde demokratik bir yapıya ve verimli bir işleyişe sahip olmalarını gerektirmektedir (Dalton, Farrell ve McAlister, 2011; Duverger, 1974:168-270; Hazan ve Rahat, 2010; Özbudun, 1979:162-166; Wright, 1971:17-54). Oysa parti içi iletişim genellikle yukarıdan aşağıya doğrudur. Ancak, parti içi demokrasiyi işletebilen ülkelerde aşağıdan yukarıya doğru da bilgi ve öneri akışı görülür. Dolayısıyla, siyasal partilerin böyle demokratik bir iç düzen kurabilmelerinin ilk koşulu, parti istencinin aşağıdan yukarıya doğru oluşmasını sağlayacak bir örgütlenmedir (Barnes, 1971:84-98; Kabasakal, 1995:142; Sartori, 1977:56-70; Teziç, 1976:90-91). Bunun için, üyelerin tüm örgüt çalışmalara ve seçimlere eşitçe katılabilme olanaklarının bulunmas1; yönetim organlarının belirli sürelerle düzenli olarak yenilenmesi ve partinin otoriter bir yönetime meydan vermeksizin üyelerce etkin denetimi gerekmektedir (Kabasakal, 2014:700-704; Tuncay, 2000).

\section{Türkiye'de partilerin yerel örgütlenmesi}

Türkiye'de siyasal partilerin köy ve mahalle düzeyinde örgütlenmesi Ittihat ve Terakki dönemine kadar uzanmaktadır. Anadolu ve Rumeli Müdafai Hukuk Cemiyeti, İttihat ve Terakki Cemiyetinin "kulüp" adıyla başlattığ1 bu uygulamayı yaygınlaştırmak istemiş, ülkenin içinde bulunduğu koşullar nedeniyle bu amacını ancak kısmen gerçekleştirebilmiştir (Tunaya, 1952:196-197 ve 212-214). Halk Firkası da kuruluşundan itibaren temel örgüt olarak mahalle ve köy ocaklarını kabul etmiş ve tüzügünde formal bir örgüt birimi olarak bu kuruma yer vermiştir.

Türkiye siyasetinde iktidarı elde etmede informal yerel örgütlenmenin rolü, açık biçimde Milli Selamet Partisi (MSP), Refah Partisi (RP) ve son yıllarda Adalet ve Kalkınma Partisinde (AKP) gözlenmiştir. Ancak gerek MSP ve RP'nin gerek AKP'nin yararlandığ1 bu model, Türkiye'nin çok partili demokratik hayatının ilk yıllarında görülen yerel örgütlenme biçiminden farklıdır. 1946-60 arasında Türk siyasal yaşamına damgasını vuran yerel birimler formal ocak ve bucak örgütleridir. Çalışmanın bundan sonraki 
bölümünde, Türkiye'de 1960'a kadar partilerin köy ve mahalle düzeyinde kurduklar1 "ocak" beldelerde/nahiyelerde kurduklar1 "bucak" örgütlenmesi incelenecek ve uygulamanın parti içi demokrasiye katkısı değerlendirilecektir.

\subsection{Ocak-bucak örgütlenmesi}

Cumhuriyet Halk Partisinin (CHP) ülke yönetimini tekelinde bulundurduğu siralarda bucak ve ocak örgütleri, halkevleri ve halkodalarılla yakın bir işbirliği içinde çalışmıs ve siyasal katılmayı sağlamaktan çok, bir siyasal eğitim aracı olarak kullanılmıştır. Ocak ve bucaklardaki parti örgütleri, asıl çok partili siyasal yaşama geçildiğinde önem ve etkinlik kazanmışlardır. Partilerin ocak ve bucaklarda kurduğu örgütler, Demokrat Parti (DP) hareketiyle yaygınlaşan siyasal katılmanın temel aracı olmuşlardır (Kabasakal, 1991:225-240).

1950'li yılların sonuna doğru, köylerin hemen hemen üçte ikisinde en az bir tane parti ocağı açılmış bulunmaktaydı. CHP ve DP önemli gördükleri her yerleşim merkezinde bir örgüt kurmaya çalıştıkları için parti ocağı bulunan köylerden yaklaşık yüzde 12'sinde ocak sayısı tekti (Özzbudun, 1975: 151). Kentlerde, kasabalarda, hemen her ocak yöresinde, ana kademe yönetim kuruluyla, gençlik ve kadın kollarıyla, disiplin ve danışma kurullarıyla, yer yer de işçi ve esnaf-sanatkâr komiteleriyle, büyük partilerin en az kırkarellişer kişilik aktif siyaset kadroları görev başında olurdu (Ecevit, 1981:5; Szyliowicz, 1966:147). ${ }^{2}$

Ocaklar, genel olarak bulundukları yörenin, mahalle veya köyün adını taşıyordu. Ancak, partiler, büyük mahallelerde birden çok ocak açtıklarında, buralara eski Türk büyüklerinin veya geçmişte partiye hizmet etmiş kişilerin (örneğin CHP'de Evliya Çelebi Ocağı, Reşat Şemsettin Sirer Ocağı, DP'de Şehit Muhtar Ocağı) adları veriliyordu (Kabasakal, 1991:226). Ocakların bağlı bulunduğu bucak örgütleri ise bucağın adını taşıyordu. Her bucak örgütüne sayıları 5 ile 8 arasında değişen ocak bağlıydı.

\subsubsection{Ocak ve bucaklarda örgütsel yapı}

Genellikle, bucak örgütlerinin 5-7, ocakların ise 3-5 kişiden oluşan yönetim kurulları bulunmaktaydı. CHP'nin 1950'li y1llarda İstanbul İl Başkanlığını yapan İlhami Sancar, "İl Başkanı olarak İstanbul'da bucak teşkilatını, Tarık Zafer Tunaya'dan aldığı 'Karakol teşkilati’na ait bir kitaba göre” kurduğunu belirtmektedir (Kabasakal, 1991:226).

Yönetim kurulları, ocaklarda ocağa kayıtlı tüm parti üyelerinin, bucaklarda ise ocaklardan gelen delegelerin katıldığı kongrelerde seçilmekteydi.

\footnotetext{
${ }^{2}$ Szyliowicz, araştırma yaptı̆̆ Erdemli ilçesinde, DP ve CHP'nin 3'er, Hürriyet Partisi (HP) ve Cumhuriyetçi Millet Partisinin (CMP) birer bucak örgütleri bulunduğunu, DP'nin yörede 4 ocağı, CHP'nin 3 ocağı, HP ve CMP'nin ise tüm belediye bölgesinde yalnızca 1'er ocağı olduğunu belirtmektedir (1966:150).
} 
Szyliowicz, bucak yönetim kurullarının sayıları 5-8 arasında değişen ocaklardan gelen delegelerce seçildiğini, bucak başkanının köylerdeki parti örgütüyle bucak arasında köprü kurduğunu belirtmektedir (1966:147-148). Partilerin kendi içindeki seçimler ve kongreler, mahallelerdeki, köylerdeki ocaklardan başlamaktaydı. Bu kongrelere, partinin üst kademe yöneticileri ve milletvekilleri de gitme zorunluluğunu duymakta ve katılmaktaydılar. Bülent Ecevit'in belirttiğine göre, "Her il ve ilçe yöneticisi ve her parlamenter bir ocak üyesiydi” (Kabasakal, 1991:226). Kongrelerde, parti örgütüyle ilgili işler yanında yerel sorunlar da görüşülmekteydi.

CHP'de Genel Sekreter yardımcllğı yapmış İbrahim Cüceoğlu'na göre, "sorunlar küçük birimlerde ele alındığı ve seçimler orada yapıldığ için, seçim mekanizması daha iyi işliyordu. Göstermelik kongre, ancak, hükümet komiserinin ryzasiyla olabilirdi” (Kabasakal, 1991:227).

Araştırmac1 Szyliowicz'in Mersin-Erdemli'deki gözlemleri, 1950-60 döneminde siyasal partilerde yönetim görevlerinde bulunmuş siyaset adamlarının aktardıklarından biraz farklıdır. Szyliowicz'e göre, bir ocak kongresi özetle şöyle olmaktaydı:

Gündemindeki ilk konu başkan ve yönetim kurulu seçimidir. Daha sonra konuşmalar başlar. Konuşmacılar genellikle şehirlidir ve ilçe başkanı veya yönetim kurulu üyeleridir. Köylülerin konuşması enderdir, oturur ve konukları dinlerler. Ocak başkanı usul gereği görünür ve çalışmaları özetleyen kısa bir rapor okur.

Toplantılarda, köylülerin de dilek ve yakınmalarını söylemeleri, sorunlarını tartışmaları için çaba harcanır, ama yöre halkı bunu çok ender yapar. Normal olarak ocak başkanı veya onun bir iki arkadaşı, yörenin yol, okul gereksinimi konusunda birkaç söz söylerler. Bu kongreler tek yönlüdür. Köylü buralara dinlemeye gelir. Daha sonra kahvelerde bu konular görüşülür ve yerel kamuoyu kristalleşmeye başlar (1966:173-174).

Birçok gözlemcinin gerçekten demokratik bir biçimde sürdürüldüğünü belirttiği bu kongreler seçimlerle sona ermekteydi. Seçilen ocak yönetim kurulu ilk toplantısında başkanını seçmekte ve görev bölümü yapmaktaydı. CHP'de ocak başkanı, genellikle kongrede doğrudan seçilmekteydi (Kabasakal, 1991:227).

Ocak-bucak örgütlerinin bağlı oldukları ilçe ve il yönetimleriyle ilişkisi dönemi yaşamış siyasetçiler tarafindan farklı değerlendirilmektedir: CHP'de ocak üyeliğinden, merkez yönetim kurulu üyeliğine ve genel sekreterliğe, milletvekilliğinden bakanlığa kadar çeşitli kademelerde görev yapmış Tarhan Erdem'e göre, bu ilişkiler, demokratikti, İbrahim Cüceoğlu'na göre ise "hiyerarşik düzen içinde." DP’li Sebati Ataman, bu ilişkinin şahsa göre değiştiğini vurgulayarak, "Eğer il başkanı kuvvetli bir şahsiyetse ocaklara da hakimdi” demektedir. Gazeteci-yazar Recep Bilginer'e göre, "İl örgütlerinin amacı ya kendi adamlarını ocağa seçtirmek ya da seçilmiş olanları kendi 
yanına çekmekti. Bu da karşılıklı ödün vermelere yol açtı. Bir ocak başkanı il başkanının adamı ise ona dokunulamadı" (Kabasakal, 1991:227).

\subsubsection{Ocakların işleyişi ve işlevleri}

Ocakların toplumsal ve siyasal yaşamda çok yönlü işlevleri de bulunmaktaydı. Toplumu ve üyeleri bilgilendirmeye ve bilinçlendirmeye yönelik eğitim çalışmaları bunların başında geliyordu. Bazı ocaklarda vitrine, yurttaşların okumalarını sağlamak için yandaş gazeteler asılmaktaydı. Bunlar dışında partilerin doğrudan doğruya ocaklar için çıkardıkları gazeteler de vard1. CHP Karagöz gazetesini, Demokrat Parti ise Kadı Emmi'yi çıarmaktaydı (Kabasakal, 1991:228). Bazı ocaklarda bir spor kulübünün bulunduğu da olurdu. Bu kulüpler, genellikle çevre gençlerini ocağa çekmek içindi (Topuz, 2011:145-146).

Ocakların açılışı, büyük törenlerle yapilmakta ve o civarda oturan herkesçe duyulması sağlanmaktaydı. Açılışlara, partinin üst düzey yöneticileri ve parti ileri gelenleri de katılmaktaydı. Ocak yöneticileri, o yörede oturan ve bu işe zaman ayırabilecek kişilerden seçilmekteydi. Bunlar, genellikle küçük iş sahipleri ve halkla kolaylıkla diyalog kurabilen kimselerdi.

$\mathrm{Bu}$ siyaset kadrolarında yer alanlar, çevrede herkesi tanırlardı. Herkesin nabzını günü gününe yoklayabilir, halkın isteklerini, beklentilerini, parti muhalefetteyse partinin üst kademe yöneticilerine; iktidardaysa, parti üst kademeleriyle birlikte hükümete, Devlet yönetimine, günü gününe duyurabilirlerdi. Parti veya Devlet yönetiminin karşılaştı̆̆ sorunları ya da izleme gereği duyduğu politikaları en uzak köyün en son evindeki yurttaşlara kadar duyurabilirlerdi. Bu sorunlarla veya politikalarla ilgili olarak yurttaşların görüşlerini, eleştirilerini alabilir, tepkilerini ölçebilirlerdi (Ecevit, 1981:5).

Ocaklar genellikle haftada bir toplanmaktaydı. Ocak toplantılant, aksatılmadan düzenli yapılmaktaydı. Ocakların seçim dönemleri dışında en çok uğraştı̆̆ konular, yerel sorunlardı. Ocaklar, mahalle ve köy halkıyla parti örgütü ve ülke yönetimi arasında bağ kuran bir iletişim kanalıydı. Bazı ocak ve bucak başkanları, görevleri sırasında bireysel yeteneklerini de kullanarak toplumda partilerine olan desteği artırmaya ve yeni üyeler kazanmaya çalışmaktaydılar. CHP'de Ocak üyeliğinden başlayarak, İl Başkanllğına, Genel Başkan Yardımcilığına ve Bakanlığa kadar görevler yapmış Ali Topuz, anılarını aktardığ1 kitabında CHP'nin yerel örgütleri konusunda önemli bilgiler de vermektedir. Ali Topuz, bir üniversite öğrencisiyken kendisini CHP'ye kaydeden Beylerbeyi Bucak Başkanı Ömer Akıncılar ve çalışmalarından söz ederken bir bucak başkanı profili de çizmektedir:

Çok güzel bir sesi vardı. Harika ezan okuyordu bir kere. Onun plağa okuduğu ezan ramazanlarda Türkiye radyolarında yayınlanırdı... Ömer müezzinlik yapmasını biliyor. Namaz kıldırmasını biliyor. Müezzin hastalansa onun yerine geçiyor, imam hastalansa onun yerine... Bir cenaze olduğu zaman Ömer ön safta. Cenaze levazımatçılarının yaptığı işi Ömer Akıncılar, 
Beylerbeyi'nde her cenaze için yapıyor. Parti ayrımı yok. Beylerbeyinde bir bebek doğduğu zaman aileye ilk ziyareti o yapıyor, isim verme töreninde bebeklerin kulağına Kuran ve ezan okuyor. Dügünlerde evlenenlerin başyardımcısı... Beylerbeyi'nde beşikten mezara herkesin yanında ( Topuz, 2011:147).

Ocak başkanları, yöre halkının sorunlarını saptayıp, çözümü için bunları bucak ve ilçe başkanlarına veya kamu görevlilerine duyurmaktaydılar. Szyliowicz'in belirttiğine göre, ocak ve bucak başkanları Mersin ve Erdemli'deki parti lokaline s1k s1k uğrar, yerel sorunlar ve ulusal konuları diğer parti üyeleriyle konuşurlar, köye dönerken parti yayınlarını alır, bunları köydeki arkadaşlarına açıklarlardı. O yıllarda devlet tekelinde olan radyo dışında başka bir görsel/işitsel iletişim aracı bulunmadiğından Ocak başkanlarının köylerine dönüşü köyde bir canlılık yaratır, başkanın temas ve izlenimlerini anlattığı toplantıya bütün köy katılırdı (1966:172-173). Bazen de bucak ve ilçedeki parti yöneticileri, ocakların toplantı günlerinde mahalle ve köylere giderek, toplantılara katılmakta ve ocaklara yansiyan sorunları yerinde saptamaktaydilar. ${ }^{3}$

Ocakların kamu yönetimiyle ilişkileri dönemin siyasetçileri tarafindan oldukça farklı değerlendirilmektedir. Ocak-bucak başkanlarının kamu yönetimiyle ilişkisini olumlu değerlendirenler ocakların, büyük halk kütlelerinin yöneticilere ulaşabilmesini kolaylaştırdı̆̆ını ileri sürmektedir. Bu yüzden, idareciler de ayaklarına çizmeyi çekip, köy köy dolaşmayı zorunlu görmüşlerdir. Kimileri ise, iktidar partisinin sağladığı olanaklarla nüfuzlarını artıran ocak ve bucak başkanlarının güçlerinin denetlenemez duruma geldiğini belirtmektedir (Kabasakal, 1991:228-229).

Ocak ve bucaklar, bir siyasal iletişim kanalı ve bir siyasal toplumsallaşma aracı olarak da önemli işlevler yüklenmişlerdi. Yurttaşlar burada bir tür siyasal eğitim görmekte, devlet yönetiminin işleyişi konusunda bilgi edinmekte, kamu yönetimiyle nasıl ilişki kuracaklarını öğrenmekteydi. Eminönü İlçe Kadın Kolu Başkanı olduktan sonra Binbirdirek Ocağı Yönetim Kuruluna seçilen Nermin Neftçi, partilerin seçmene en yakın, en uçtaki ve en küçük üniteleri olan bu parti örgütlerinde politikanın çok canlı olduğunu, buralarda gazete haberlerinin CHP'nin politikalarına göre yorumlandığını, ilin siyasal dedikodularının yapıldığını anlatmaktadır (1997: 30). Ocakların, niteliği ve yoğunluğu yörelere göre değişen kültürel ve eğitsel

\footnotetext{
31950 yllında yapılan CHP 8. Büyük Kurultayına “CHP'de Islahat Yapılması için Teklif” sunan 22'si milletvekili olan 101 delege partinin geniş halk kitleleri ile sıkı ve devamlı bir temasın sağlanması için "Bucak teşkilatı kademesinin kaldırılması ve bunların Ocaklara çevrilmesinin” yerinde olacağını belirtmektedirler. Bkz. CHP'de Islabat Yapılması için Teklif, 1950, Yeni Matbaa, Ankara.
} 
çalışmaları da olmaktadır. Konferanslar, gösteriler düzenlenmekte, sohbet toplantilar1 yapilmaktadir.

Tek parti döneminde CHP'nin, daha sonra da DP'nin Kuzguncuk Ocak Başkanlığını yapan Samim Yücedere ocak çalışmalarıyla ilgili olarak şunları anlatmaktadır: "Okuma yazması cok az olan insanlar bu ocaklarda, Devlet nedir, bükü̈met nedir? ögrenirlerdi. Bicki-dikiş kursu yaptık. Ben isteyenlere Ingilizce dersi verdirdim. Bunu DP döneminde de uyguladim. Ocak yöneticileri, Büyülkada'da parçalanmak. üzere olan bir aileyi birlestirmistir. Ocaklarn köyün ve maballenin sosyal hayatinda büyük yeri vardi" (Kabasakal, 1991:229).

Ocaklar, partiye sempatisi olan insanlanı, delege ve yönetici olarak aktif biçimde siyasete katan bir araç görevi de yapmaktaydılar. Halkın katkısı hem siyasal katılma hem de maddi katılma şeklinde olmaktaydı. Bu yüzden, 1960 öncesinde partilere devlet yardımı olmadığı halde, maddi sıkıntı çekilmiyordu. $\mathrm{Bu}$ örgüt birimleri kendi giderlerini, üyelerinden topladıkları ödentilerle kendileri karşılıyorlardı. Ödentiler, her yerde düzenli toplanamamakla birlikte yine de gelirlerin önemli kısmını oluşturmaktaydı. ${ }^{4}$

Köylerde ise ocak başkanı, yurttaşlardan koyun, kuzu, deri vb. ürünleri bağ1ş olarak almakta, bunları satarak gelirini partiye vermekteydi. Tarhan Erdem'in belirttiğine göre, bazı ocaklarda aidat kartları vardı ve üyelerin en az yüzde 30'undan ödenti alınırdı. İstanbul'da parti gelirinin önemli bir kısmı aidat geliriydi. Ocaklar ayrıca çeşitli toplantılar düzenler, lokaller işletirdi (Kabasakal, 1991:230).

Ocaklar, en önemli işlevlerinden birini seçimler sırasında yerine getirmekteydiler. Seçimlerde partili sandık gözlemcileri ocaklardan seçilmekteydi. Bu gözlemciler yörede yaşayan yurttaşları tanıdıkları için, seçim yolsuzlukları ve usulsüzlükleri önlenmekte, seçim güvenliği daha kolay sağlanmaktaydı. Ocak teşkilatı ile üye ilişkilerine gelince, genelleme yapmaya imkan vermese de bu konuda en ayrıntılı bilgi Neftçi'nin anılarında yer almaktadır:

Üyeler vardır, Partiye yazılırlar hiç gelmezler, semtine uğramazlar ama seçimlerde aileleri ile oy verirler. Bir görev istemezler, ara sıra seçimlerde çalısmak için çağırılılılarsa, geçici görevler alırlar. O partinin programlarının ülkeye yararlı olacağı inancındadırlar. Üyeler vardır eskiden kalma ya da babadan görme. Bunlardan bir bölümü görev ister, sağa sola da koşturur, aidatlarını öderler. Öyle üyeler de vardır ki ne iş verirseniz yaparlar. Karşılama törenlerinde, mitinglerde sesleri kısılıncaya dek bağıranlar, sandık

\footnotetext{
4 Szyliowicz, ödentilerin yasal olarak verilmesi gerektiğini, ancak yalnızca birkaç köylünün siyasal inançlarını parasal katkıyla desteklemeye istekli olduklarını, bu güçlügün bütün partilerde görüldüğünü, örneğin CHP'nin o zaman 1 lira olan ödentisinin birçok yerde güçlükle toplanabildiğini belirtmiştir. Szyliowicz'e göre, DP, harcamalarını yerel gelirlerle karşılamak konusunda CHP'den daha başarılıdır. CHP gelirlerinin yaklaşık yüzde 50'si il örgütlerinden sağlanmaktadır (1966:150).
} 
görevi alabilmek için yarışanlar, gerektiğinde parti büyüklerine, parti binalarına koruyuculuk yapanlar, parası pulu varsa son kuruşuna kadar verenler bunların arasından çıkar. Içlerinde okuyup yazma bilmeyenlerinden tutun da kendi dallarında uzmanlaşmış kişilere, beş parasızından milyonerine kadar bulunabilir.

... Bazı kişiler vardır, çevrelerinde sevilirler, sayılırlar. Ĕger sempatizansa yöneticiler onları partiye alır. Yönetim kurullarına seçtirirler. Kimi bir işe yarar kimi yaramaz. Bunlar çoğunluk, emeklilerden çıkar. Bazen da sağmallık için paralılar arasından seçilirler.

... Bir de, niçin yazıldığını bilmeyen, parti, particilik nedir anlamamış, bir tutunacak dal olsun, boş gezeceğine bir uğraş olsun diye partili olanlar da vardır (1997:30-31).

O zamanlar parti teşkilatlarının en küçük birimi olan ocakların yöneticileri bile yörenin partiyi destekleyen gerçek delegeleri tarafindan seçilirlerdi. Herkes seçeceği kişiyi iyi tanırdı. Seçimler tam olarak yasalara uygun yapılırdı (Neftçi, 1997:33). Bu nitelikleriyle ocaklar, parti içi demokrasinin de daha iyi işlemesine katkı sağlamışlardır. Ecevit'e göre, 1960 öncesi partilerde önseçim diye, delege hilesi diye bir sorun yoktu. Ecevit, ocak-bucak örgütlerinin Türk siyasetine ve parti içi demokrasiye katkısını şöyle değerlendirmektedir:

Partililer, seçimden seçime değil, ocaklarda her gün bir araya gelir, olayları ve politikacıları birlikte tartışıp değerlendirir, parti içi seçimlerde bilgiyle ve bilinçle oy kullanabilirlerdi.

Parlamentoya seçilmek isteyenler, en uzak köylere kadar gitmek, köyün derdini köylüden, mahallenin derdini mahalleliden dinlemek ve seçilirlerse neler yapmaları gerektiğini halktan öğrenmek veya sorunlara nasıl çözümler getirmeyi düşündüklerini halka anlatıp danışmak zorundaydılar.

Milletvekili seçildikten sonra da Ankara'ya kapanıp kalmazdı politikacılar... Önseçim oyunları diye bir şey bilinmezdi o dönemde. Delegelikler ve aday yoklamaları masa başında ayarlanamazdı. İstense de kolay çevrilemezdi o türlü oyunlar... Bir köyde veya mahallede partili seçmen iradesini oyuna getirmenin yolu bulunsa, başka mahallelerde veya köylerde oyun bozuluverirdi (Ecevit, 1981:5-6).

\subsubsection{Ocak-bucak örgütlerinin değerlendirilmesi}

Ocak ve bucak örgütlenmesinin siyasal yaşama bütün bu olumlu katkılarına karşın, zaman zaman ve bazı yörelerde yanlış uygulamalar ve yozlaşmalar da olmuştur. Bazı ocak başkanları kendilerine rakip olabilecek kimseleri partiye almak istememişler; bazen ilçe başkanıyla işbirliği içindeki ocak başkanı, köyde yıllarca çalışan partililerin delege olmasını engellemiş, kırgınlıklara neden olmuştur. Ocak başkanı, çevrede sevilmeyen bir kişi ise, tutumu ve uygulamaları partiye mal edilmiş, bu yüzden kimi yerlerde yurttaşlar partiden uzaklaşmışlardır (Kabasakal, 1991:230). Ancak, bütün bu 
olumsuzluklar, "insan" öğesinden kaynaklanmaktadır ve partilerin her düzeydeki yöneticisi için geçerlidir.

Türkiye, 1959 yllı sonlarından itibaren yeni bir siyasal gerginlik dönemine girmiştir. Bir yandan DP, 'Vatan Cephesi Ocakları' adıyla yeni ocaklar açarken, diğer yandan CHP, mevcut ocaklarının sayısını arttırmaya çalışışıtır. Ancak, bu yarış Ankara'daki siyasal gerilimin, değişik ölçülerde de olsa tüm ülkeye yansımasına neden olmuştur. Bu yüzden partilerin mahalle ve köylerdeki örgütlerinin, yurttaşlar arasında kutuplaşmalar yarattığı, kahveleri bile ayırdığ görüşü birçok kişi tarafindan ileri sürülmüştür. $\mathrm{Bu}$ eleştirilere katılmayanlar, sözü edilen olumsuzlukların en önemli nedenlerinden birinin, parti liderlerinin kutuplaştırıcı tutumu olduğu düşüncesindedirler (Kabasakal, 1991:231).

27 Mayıs 1960'da DP Hükümeti bir askeri müdahale ile devrilmiş, ihtilali yapan orta rütbeli 38 subaydan oluşan Milli Birlik Komitesi (MBK), 28 Mayıs tarihli bir kararla partilerin siyasal faaliyetlerini durdurmuştur. MBK 4 Temmuz 1960'da kabul ettiği 8 Sayll Kanunla "siyasal partilerin il ve ilçe merkezleri dışında her ne ad ile olursa olsun örgüt kurmalarını" yasaklamış ve il ve ilçe örgütleri dışında kalan tüm teşkilatlarını kaldırılmıştır. ${ }^{5}$ Dönemin CHP Genel Başkanı İsmet İnönü bu karara ilk karşı çıkanlardan biri olarak, siyasal partilerin ocak-bucak örgütlerinin kaldırılması kararına ilişkin itirazlarını şöyle açıklamaktaydı:

... ocak ve bucaklar, teşkilatlarını siyasi partinin mahdut bir zümresinin terkibi şeklinden kurtarıp, geniş halk tabakasına mal etmişlerdir. Bundan daha ehemmiyetli olarak, memleket meselelerinin ve devlet idaresi düşüncesinin vatandaş topluluklarının dertleri ve istekleri çerçevesinin dışında kalmış olan geniş halk kitlesini siyasi terbiyenin içine almış, memleket meseleleri ile en küçük vatandaşı ilgilendirmiştir. Ocak ve bucaklarda vatandaşlar bir siyasi mektepte olduğu gibi alş̧ışs ve yetişmişlerdir. Merkezi idarenin doğru yoldan ayrilması ihtimalinde, murakabenin (denetimin) köylere kadar şümullü ve tesirli bulunması en büyük teminattır. ${ }^{6}$

Ocak-bucak örgütlenmesine karşı çıkanlar, başlıca şu gerekçeleri ileri sürmekteydiler:

1. Siyasal partilerin mali denetiminin Anayasa Mahkemesine bağlanması nedeniyle kırk binden fazla ocak örgütü olan bir partide bu denetimi yapmak kolay değildir.

2. Kırk bin köye gerekli parti malzemesini göndermek, parti merkezlerine büyük bir maddi yük getirecektir.

53512 Sayll Cemiyetler Kanununa ek Geçici Kanun: Kanun No. 8, Kabul Tarihi 4.7.1960, Yayın Tarihi 5.7.1960. Bkz. Cumburiyet, 7 Temmuz 1960.

${ }^{6}$ Cumburiyet, 6 Temmuz 1960. 
3. Ocak-bucak örgütü, halkın gerçek gereksinmelerini saptamaz ve temsil etmez.

4. Ocak-bucak örgütlenmesi köylerde kahvelerin ayrilmasına varacak kadar husumet cepheleri oluşturmuştur (Bosuter, 1969:76-77).

TBMM'de bu görüşler ağır basmış olmalı ki, 1965 yilında çıkarılan Siyasi Partiler Kanununun 17. madde 2. fikrası partilerin ocak-bucak örgütleriyle ilgili yasaklamayı benimsemiştir. Bu yasa tasarısının TBMM'nde görüşülmesi sırasında yoğun tartışmalar yaşanmıştır. Bazı üyeler, tasarıya şiddetle karşı çıkarak, partilerin köylerde yeniden ocaklar açmasını istemişlerdir. Talat Oğuz’a göre, “...köylümür için siyasi mektep olan ocak-bucak teskkilatlarmm yasaklanmasi, siyasi ve tabii baklar kistlamakla anti-demokratiktir." " AP Milletvekili Nihat Diler ise TBMM'deki konuşmasında "Siyasi Partiler tasarsimn partilere Türk balkimn yüzde 75'inin yasaduğ köylerde teskilatlanma imkânm sağlamaması sakincalıdrr. Siyasi partiler özerkliğe kavusturulacaklar yerde, bu tasar ile vesayet altna alnmaktadrrlar" demekteydi (1964). Tasariy1 savunanlardan Coşkun Kırca (1965) ise, şu görüşleri ileri sürmekteydi:

Bizde ocak-bucak saltanatının temsilcisi olan tip, aslında kendini seçen alt tabakanın temsilcisi olmaktan ziyade, gerçekleri o tabakaya başka türlü anlatmak yahut menfaat temin etmekte aracı olmak suretiyle kudret tesis etmiştir. Alt tabaka iradesinin üst tabakalara intikalinde bu oligarşik grupların bir mania tesiri oynadıkları şüphesidir... Şimdi biz istiyoruz ki köyde veya mahallede bulunan partili, partinin iradesine aracı vasitasılyla değil, mümkün mertebe kendisi hakim olsun... O halde fark, ocak idare heyetinin ortadan kaldirlmasindan ibarettir. Aslinda ocak idare heyeti namına iş gören adam, ocak başkanı olmuştur. Bizim yaptığımız şey, ocak başkanını bir idare heyetine seçtirmek yerine, doğrudan doğruya partililere seçtirmekten ibarettir. ${ }^{8}$

Yoğun tartışmalardan sonra 13 Temmuz 1965 tarihinde kabul edilen 648 Sayılı Siyasi Partiler Kanunu, ülkedeki bütün siyasal partileri "aynı modele göre örgütlenme" zorunda bırakmıştır. Yasa, siyasal partilerin kendi siyasal doğrultularının gereği olarak, farklı biçimde örgütlenme olanaklarını kısıtlamıştır. Yasaya göre, siyasal partiler, ancak köy ve mahalle muhtarlık bölgelerinde parti işlerinin yürütülmesi için parti görevlileri belirleyebileceklerdi. Parti görevlisi, o muhtarlık bölgesindeki parti üyeleri tarafindan parti tüzüğgüne göre seçilecekti (md. 17, f.1). Teziç'e göre (1976: 67), bu yüzden "Siyasi Partiler Kanununda parti genel örgüt șemast içinde köjlii yuğnlar faal siyasal bayatın dișına itilmişs olwyor"du.

\footnotetext{
7 Talat Oğuz ve Nihat Diler'in konuşmaları için bkz. Millet Meclisi Tutanak Dergisi, B. 74, 12.3.1965, s.364. Reşit Ülker ve Tahsin Turgay da benzeri konuşmalar yapmışlar ve bu sınırlamanın Anayasanın parti kurma özgürlüğü tanıyan 56. maddesine aykırı olduğunu ileri sürmüşlerdir.

8 Kırca’nın konuşmasında söz ettiği “ocak başkanını bir idare heyetine seçtirmek yerine, doğrudan doğruya partililere seçtirme” fikri çıkarılan yasada yer almamıştır.
} 
Ocak bucak örgütleriyle ilgili en çarpıcı değerlendirmelerden birini Adalet Partisi Genel Başkanı Süleyman Demirel yapmıştır: "Ocak bucak teşkilatı Türkiye'yi harekete geçirmiş, uyandirmıştrr. Ocak bucak kaldirlinca da tartş̧ma yine këy ortalarnda yapılmıștır. Bunun (ocak ve bucakları kastediyor), yer yer ölçüsünün kaçurldiğ olaylar vardir. Bunlar kalkenca, siyaset şebirlinin malı oldu. Oysa köyde yasayanlar, nüfusun yüzde 60' 'O boşluğu ögretmen -TÖS, TÖBDER- ve imam MSP- doldurdu." Demirel, "Ocak bucak tesskilat yapillrsa, illegal fikrin karsısına

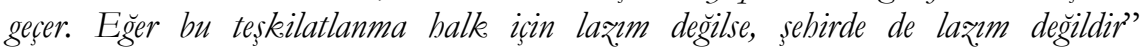
demektedir (Kabasakal, 1991:234).

Siyasal partilerin, bucak, mahalle ve köylerde örgüt kurmalar1 yasaklanınca, partilerin bazı işlevlerinde aksamalar olmuş ve bir boşluk doğmuştur. Partiler, ocak ve bucak örgütleriyle yürüttükleri görevleri, il ve ilçe yönetim kurullarınca yürütmek durumunda kalmışlardır. $\mathrm{Bu}$ yüzden partilerin yan kuruluşlarının eski canlılıklarını yitirdikleri bile ileri sürülmüştür (Ecevit, 1981:6). Ocak ve bucak örgütlerinin kaldırılmasıyla, partilerin üye kayıtlarındaki usulsüzlükleri denetlemek güçleşmiş, il ve ilçe örgütlerinde çalışanların köye gitmesini özendirici etkenler ortadan kalkmış, partilerin toplumla ilişkileri gitgide azalmıştır. 1970'li yıllarda Senato Başkanlığ yapmış olan Sirn1 Atalay, "Ocaklar kaldrrldağznda Ankara'ya gelen ve köyünü temsil ettiğini söyleyen partilinin o köyü gerçekten temsil edip etmedig̈i tartışmalyydi" demekteydi (Kabasakal, 1991:233).

Yasaklama kararının parti içi demokrasiyi etkileyen sonuçları da olmuştur. Üyelerin yereldeki doğrudan denetimi ortadan kalkınca, delege seçimlerini kapalı odalarda ve masa başında yapma geleneği oluşmaya başlamış, bu yüzden de parti içi seçimler, aday yoklamaları inandırıcıllğını yitirmiştir (Ecevit, 1976:56). Oysa 1950'li yllarda yerel örgütler adaylar1 kendileri belirlemekte olup, ulusal kongrelerde de etkili idiler. Örneğin, 1949'da, DP II. Büyük Kongresinde milletvekili adaylarının yüzde 80'inin örgütçe, yüzde 20'sinin ise Genel İdare Kurulu tarafindan aday gösterilmesine karar verilmiştir. Benzer şekilde, CHP'nin 1951 Kurultayında yapılan Tüzük değişikliği ile milletvekili adaylarının tümünün yerel örgütler tarafindan saptanması kararlaştırlmıştır. Bu örnekler, parti içi demokrasinin 1950'lerde günümüzdekinden daha iyi işlediğinin de somut kanıtlarıdır. Ecevit'e göre, ocak ve bucakların kapatılmasıyla, adaylar ve milletvekilleri, artık demokrasinin gereği de olsa, kendilerini köylüyle yani vatandaş çoğunluğuyla temasa mecbur hissetmeyeceklerdir. Adayların saptanmasinda parti genel merkezlerinin etkisi artacağ uzaklaşacaktır (Ecevit, 1960a, 1960b). Mümtaz Soysal'ın bu konudaki düşünceleri ise şöyledir:

... Eğer lider sultaları ortaya çıkmışa, bu biraz da politikacılarımızın tutunabilecekleri yerel dalları kesişimizdendir... Ocak ve bucak örgütlerinin kaldır1lışıyla ortaya çıkan boşluk, görünürdeki partiler dışında yasa dışı örgütlerce ya da yasal partilerin çeteleşmiş silahlı kollarınca doldurulmuştur (1982). 
Özetle, siyasal partilerin ocak ve bucak örgütlerinin kaldırılmasıyla, Türkiye siyasal katılmayı ve demokratik rejim içinde bilinçli siyasal eylemi sağlayan önemli bir araçtan yoksun kalmıştır. Özbudun'un bir çalışmasında yer verdiği araştırma sonuçları bu görüşü desteklemektedir:

Türkiye'de seçime katılma oranının en yüksek olduğu köyler, 1960 öncesinde bir siyasal parti ocağına sahip bulunmayan köylerdir... Diğer bir deyimle, azgelişmiş köylerde yüksek oranda seçime katılma, siyasal parti eylemlerinden geniş ölçüde etkilenmenin yani siyasallaşmanın bir sonucu olarak görünmemektedir. Siyasal parti eylemlerinden uzak olan köylerde yüksek katılma oranları, bu bölgelerdeki mobilize (güdümlü) katılmanın güçlü bir kanıtı olarak kabul edilebilir (1975:153).

\subsection{Farklı bir yerel örgütlenme modeli}

Türkiye siyasetinde iktidar1 elde edip sürdürmede yerel örgütlenmenin katkıs1, açık biçimde Milli Selamet Partisi (MSP), Refah Partisi (RP) ve Adalet ve Kalkınma Partisinin (AKP) tüzüklerinde yer almayan informal örgütlenmesinde gözlenmiştir. $\mathrm{Bu}$ partiler, yerel örgütleri kanalıyla farklı İslami cemaat ve tarikatların kendi derneklerini kurarak ya da tabelasız olarak örgütlenmelerinden yararlanmışlardır (Özbudun ve Hale, 2010:50-54). AKP'nin yerel düzeydeki bu faaliyetleri, parti içi demokrasinin işleyişine katk1 sunamasa bile üzerinde durulmaya değer bir yerel örgütlenme modelidir. AKP'nin, RP'nin büyük şehirlerin çeperlerinden aldığ1 hatır1 sayılır oyları yükselterek iktidar olmasında bu örgütlenmenin payı büyüktür. AKP yerelde İslami örgütlenmelere ve faaliyetlere kolaylıklar sağlamış, hemşeri gruplarının desteğini almaya önem vermiş, sivil toplum kuruluşlarıyla iletişime geçerek, faal olanları belirleyip onlarla çeşitli organizasyonlar düzenlemiştir (Aslan-Akman, 2012:169).

AKP'nin yerel düzeyde örgütü, diğer partilerde olduğu gibi, belde, ilçe ve il yönetimlerinden oluşmaktadır. Tüzüğe göre en küçük birim, belde kongresince seçilen belde başkanı ve belde yönetim kurulundan oluşmaktadır. "Bununla birlikte belde kademesinin altında, mahalle, köy ve sandık bölgelerinde temsilcilikler veya üç kişiden az olmayan temsilci kurullar" oluşturulabilmektedir. Türkiye'de partilerin pek çoğunda görüldüğü gibi AKP'nin de çok merkeziyetçi ve hiyerarşik bir yapısı vardır (Özbudun ve Hale, 2010:94).

AKP'nin yerel örgütleri, Türkiye'deki diğer siyasal partilere oranla informal yapılardan da yararlanarak daha iyi örgütlenmiş ve daha aktif görünümdedirler. Yerel örgüt yapısında ilçe yönetimlerine bağlı üç kademe bulunmaktadır: Belde, mahalle ve sandık örgütlenmesi. Seçim sandığı örgütü, partinin seçmene eriştiği kılcal damarlardır. "Bunlar, parti sempatileri ne olursa olsun, bütün seçmenlerle temas kurmayı amaçlamakta ve faaliyetlerinde sıradan AKP üyelerinin yardımlarını da sağlamaktadır" (Özbudun ve Hale, 2010:98). 
Türkiye'de parti örgütünün yereldeki işleyişini ele alan en yeni araştırmalardan biri Sevinç Doğan'ın İstanbul'un Sanayi Mahallesinde yürüttüğü AKP ile ilgili çalışmadır. Doğan’a göre, “AKP 2001 ynlinda kurulduğunda kadrolarm ve teskilat birimlerini hr:̨la olusturmasmdaki en önemli etkenlerden biri, RP dönemi pratiklerine yaslanmasydi" (Doğan, 2017:42-43). Doğan'ın gözlemleri AKP'ye yakın kuruluşların mahalle düzeyinde çalışmaları hakkında önemli bilgiler içermekte ve AKP'nin yerel örgütlenmesine 1şık tutmaktadır:

Mahallede oldukça etkin kurumlardan biri Araştırma ve Kültür Vakfiydı. Kurum bünyesinde olan Pınar Yayınevi eğitim alanında kimi etkinlikler yapıyor, hadis dersleri veriyor, Arapça kurslar açıyordu. Enderun Eğitim Vakfi, Kardelen Yardımlaşma ve Dayanışma Derneği, Sadabad İlim ve Hizmet Derneği, Suffa Vakfi, Vuslat Derneği, Günıșığı Derneği gibi öğrencilere burs yardımında bulunan, çocuk kitapları ya da dergileri çıkaran, kutlu doğum programları yapan, gida yardımında bulunan kurumlar da vardı. Pek çok ilde şubesi olan Kur'ana Hizmet Vakfi, merkezi Fatih'te olan Akabe Eğitim ve Kültür Vakfı da mahallede etkindiler.

İsmailağa Cemaati, Cübbeliler Grubu, Menzil Cemaati gibi oluşumlar bu vakıf ya da kültür merkezlerinin yürütücülüğünü yapıyordu. Camilerin çay ocakları da ortak mekanlar olarak işlevseldi...

Gülen Cemaati, mahallede abi ve abla evleriyle varlık gösteren aktörlerden biriydi. AKP'nin cemaatle çalışmaları tamamen ayrıydı. Aralarında örgütsel bir birlik ve kaynaşma yoktu.

Cemaat üyelerinin, yerel parti örgütü içinde sayıca ya da nitelik olarak kayda değer bir güce sahip olmadıkları, kritik konumlarda yer almadıkları ve daha çok üst düzey konumlarda temsiliyetleri olduğu anlaşllyyordu (Doğan, 2017: 65-66).

AKP yerelde İslami oluşumlarla dengeli bir ilişki kurmaya ve sürdürmeye çalışıyordu. İslami örgütlenmelere ve faaliyetlerine yerelde kolaylıklar da sağlıyordu (Doğan, 2017:66-67). Doğan'in Sanayi Mahallesi çalışması, mahalle düzeyinde de olsa AKP'nin sivil toplum kuruluşlarıyla ilişkileri konusunda değerli bilgiler içermektedir:

Sanayi Mahallesi özelindeki sivil toplum kuruluşları arasında İmam Hatipliler Derneği Mezunları önemli bir yere sahipti... Diğer sivil toplum kuruluşları arasında değerlendirilebilecek hemşehri dernekleri de siyasal alanda hala önemli bir yere sahipti... Parti yerelde hemşehri gruplarının desteğini almaya önem veriyor, mahalle ve ilçe yönetimlerinde bu grupların temsiliyetine özen gösteriyordu... Ayrıca, kadın yardımlaşma dernekleri, okul dernekleri, mahalle güzelleştirme dernekleri de halkla ilişkiler biriminin temas halinde olduğu sosyal amaçlı sivil toplum kuruluşları arasındaydı. Bunlar dışında amatör spor kulüpleri de siyasal çevrelerin dolaylı olarak hitap ettiği sosyalleşme mekanlarıdı... Parti birimleri, bu dernek ve sivil toplum kuruluşlarılya iletişime geçiyor, faal olanları belirliyor ve bunlarla organizasyonlar düzenliyordu (Doğan, 2017:68). 
Özbudun ve Hale'nin belirttiğine göre, AKP “Bu tür programlar yoluyla ihtiyaç sahibi ailelere, görünüşte parti farkı gözetilmeksizin, yiyecek, kömür, nakit ve diğer yardımları" ulaştırmaktadır (Özbudun ve Hale, 2010:98-99). Doğan'a göre, Parti, kanaat önderi sayllan siyasal ve ekonomik anlamda nüfuzlu kesimlerle de iletişim kuruyordu. AKP'nin “çevre çeperinde yer alan kanaat önderleri arasında geçmişte hükümette ya da belediyelerde görev almış eski meclis üyeleri, işadamları, ilim erbabı, yaşlı ve tecrübeli insanlar olabiliyordu. $\mathrm{Bu}$ kişiler çevrelerinin ve hemşehri gruplarının siyasi yönelimlerinde etkiliydi", bazıları mahalle ile genel merkez arasında formal olarak görünmeyen bir iletişim ağı kuruyorlardı. Parti, mahalleden gelen siyasal taleplerin "içeriğini sınırlandırma ve meşru siyasal eylemin biçimini çizmede hegemonik bir etkiye sahip görünüyordu” (Doğan, 2017:68-69).

Doğan’a göre, Parti örgütlenmesi içinde ilden ilçeye, oradan mahalleye zincirleme bir hiyerarşi vardır. İl Örgütlenmesine benzer bir yap1 ilçe ve mahalle örgütlenmesi için de geçerlidir. "Örneğin, Mahalle Yürütme Kurulu, Mahalle Teşkilat Başkanı, Seçim İşleri Başkanı, Tanıtım ve Medya Bakanı, Sosyal İşler Başkanı, Yerel Yönetimler Başkanı, Halkla İlişkiler Başkanı ve Sekreterden oluşur." İlçe yürütme kurulunda ise bunlara ek olarak Siyasi ve Hukuki İşler Başkanı, Dış İlişkiler Başkanı, Mali ve İdari İşler Başkanı (İlçe saymanı) Araştırma ve Geliştirme Başkanı yer almaktadır. Bu yapıda başkanlar belirleyici konumdadır, ilçe başkanı kendi yönetim ekibini oluşturur. Teşkilat başkanı başta olmak üzere ilçe yönetim kurulu üyeleri mahalle başkanlarının bulunmasında ve seçilmesinde etkin rol oynarlar (2017:70). "Parti teşkilatlanması içinde resmi bir statüsü bulunmasa da mahalle ve sandık bölgelerinin parti çalışmalarının temel zemini olduğu" anlaşılmaktadır (2017:71).

Yerel parti örgütünün günlük işleyişi belirlenmiş bir çerçeve içinde tekdüzedir. Buna göre partililer haftalık ve aylık toplantılara katılırlar, esnaf dernek ve ev ziyareti yaparlar, taziye hasta ziyareti ya da kutlamalarda bulunurlar. Diğer ilçe ve il yönetimiyle de eşgüdüm sağlanır. Ancak, asıl çalışmalar seçim dönemlerinde il yönetiminin çizdiği rotaya göre yürütülür (Doğan, 2017:71). Parti içi eğitim, ulusal düzeyde olduğu gibi, yerel parti faaliyetlerinin de önemli bir parçasıdır.

AKP'de yerleşik kurum kültürü, hiyerarşik yapının sorgulanmasına izin vermese de yerelde "nihai söz yetkisine sahip genel merkezin kararlarına karş1 ç1kanlar” olduğu görülebilmektedir (Doğan, 2017:72). Doğan’a göre, "Parti, yerelde siyasetin kapsamm daraltiyor ve onu uzmanlik gerektiren bir is olarak genis kesimlerin yapamayacağ bir tanıma ve kossullara bağhyor" du (2017:102).

\section{Formal ve informal örgütlenme modellerinin karşılaştırılması}

Çalışmanın önceki bölümlerinde 'Türkiye'de yerel düzeyde ilki, 1946-60 arasında uygulanmış formal, diğeri 1970’lerden günümüze kadar devam eden 
informal örgütlenmeler üzerinde duruldu. Tablo.1'de, bu bilgiler ışı̆̆ında, her iki örgütlenme modelinin çeşitli işlevleri karşılaştırılmaktadır. Formal modele ilişkin daha detaylı ve kapsamlı bilgilere karşın, informal modelle ilgili bilgilerin sadece bir mahalleye ait gözlemlere ve sınırlı sayıda literatüre dayanması bu karşılaştırmaya bazı kısıtlar getirmektedir. Kaldı ki formal modelin uygulandığı tarihte, sosyal medyanın bulunmadığını, iletişim imkanlarının ve ülke kaynaklarının sınırlı olduğunu da değerlendirmede dikkate almak gerekir. Ancak, her şeye rağmen Tablo.1 her iki modelin de işlevlerinin daha iyi anlaşılmasına yardımcı olacak bilgiler içermektedir.

Her iki örgüt modelinde de yerel örgütlerin seçimlerde partilerine oy verenlerin sayısını artırmaya yönelik çabaları vardır. Fakat formal modelde siyasete katıllım bireyin kendi iradesiyle gerçekleşirken informal modelde katılım güdümlüdür. Gerçi formal modelin uygulandığı 1950’li yıllarda Doğu ve Güneydoğu Anadolu'da aşiret ağaları ve şeyhlerin etkili olduğu bölgelerde de mobilize/güdümlü katıllım söz konusu olmuştur.

Türkiye'de çok partili siyasal yaşamın her döneminde hükümetle işleri olan bazı yurttaşlar, işlerini daha rahat yürütebilmek amacıyla özellikle iktidar partisine üye olmakta ve üye kimliği ile bakanlıklarda işlerini daha rahat yürütebilmektedirler. $\mathrm{Bu}$ kapsamda, formal model partiye yeni üye kazandırmayı öngörürken, informal modelin özellikle yeni üye kazanma hedefi yoktur.

Seçim faaliyetlerini yürütme, her iki modelde de yerel birimlerin asli işlevleri arasında yer alır. Sandık görevlilerini belirleme formal örgütün doğrudan görevleri arasındadır. Formal örgütün seçilmiş bir birim başkanı vardır. İnformal modelde partinin seçilmiş ilçe ve il başkanı siyasal temsil yetkisine sahiptir ve bu yetkisini paylaşmaz. Aday belirlemede, formal yapının aksine, informal örgütlerin söz hakkı yoktur. Formal yapılarda da aday belirleme yetkisi ancak parti tüzügünde yer almıs ise uygulanabilir. Örneğin, 1950’li yıllarda tüzük kuralları ve kurultay kararları doğrultusunda CHP adaylarının tamamı, DP adaylarının ise \% 80'i yerel formal örgütlerce belirleniyordu. 
Tablo 1. Formal ve informal yerel örgütlerin işlevler açısından karşılaştırılması

\begin{tabular}{|l|c|c|}
\hline İşlevler & $\begin{array}{c}\text { Formal } \\
\text { Örgütlenme } \\
\text { Ocak-bucak } \\
\text { örgütleri } \\
\text { (CHP-DP) }\end{array}$ & $\begin{array}{c}\text { İnformal } \\
\text { Örgütlenme } \\
\text { Mahalle ve sandık } \\
\text { örgütleri } \\
\text { (MSP- RP-AKP) }\end{array}$ \\
\hline Siyasal katılımı artırma & $\checkmark$ & $\checkmark$ \\
\hline Mobilize katılımı sağlama & $\checkmark$ & $\checkmark$ \\
\hline Yeni üye kazandırma & $\checkmark$ & \\
\hline Seçim faaliyeti yürütme & $\checkmark$ & \\
\hline Siyasal temsil & $\checkmark$ & $\checkmark$ \\
\hline Aday belirleme & $\checkmark$ & $\checkmark$ \\
\hline Ülke siyasetini tartışma & $\checkmark$ & $\checkmark$ \\
\hline Parti siyasetine katk1 & $\checkmark$ & \\
\hline Parti finansmanına katkı & $\checkmark$ & \\
\hline Sivil toplumla ilişkiler yürütme & & $\checkmark$ \\
\hline Cemaat-tarikat ilişkileri yürütme & $\checkmark$ & \\
\hline $\begin{array}{l}\text { Seçmene-üyeye menfaat } \\
\text { sağlama }\end{array}$ & $\checkmark$ & \\
\hline $\begin{array}{l}\text { Seçmen sorunlarına çözüm } \\
\text { arama }\end{array}$ & $\checkmark$ & \\
\hline Yerel sorunları görüşme & $\checkmark$ & \\
\hline Seçmen ve üye eğitimi & $\checkmark$ & \\
\hline $\begin{array}{l}\text { Seçim sandı̆̆1 görevlerini } \\
\text { yönetme }\end{array}$ & $\checkmark$ & \\
\hline Siyasal iletişim sağlama & $\checkmark$ & \\
\hline
\end{tabular}

Kaynak: Tablo, yazar tarafından, taranan literatüre dayalı olarak geliştirilmiştir.

Her iki modelde de yerel birimlerde ülke siyasetine yönelik görüşmeler yapılıyor olmakla birlikte, Sevinç Doğan'ın aktardığına göre, AKP'de bu çalışmalar iki yönlü tartışmadan ziyade, tek yönlü bilgi aktarımının ağırlık taşıdığ1 yönündedir. Formal model, yerel birimlerin parti program ve politikalarının oluşturulmasına imkan tanımaktadır. Partinin finansmanına katkı her iki modelde yerel örgütlerin işlevleri arasındadır.

Siyasal iletişim her iki modelde de yerel örgütlerin işlevleri arasında sayılabilir. Ancak, iletişim kanallarının sınırlı olduğu 1946-60 arasında ocakbucak örgütleri gerçekten siyasal iletişim alanında etkin işlev görmüşlerdir. 1950'li y1llarda sivil toplum kuruluşlarının sayısının çok sinırlı olmasına karşın, partilerin ocak bucak örgütleri az sayıda da olsa sendikalarla, derneklerle meslek kuruluşlarıyla ilişki kurabiliyordu. Cemaat ve tarikatlar ise kendi içlerinde demokrasiyi işleten formal ve yasal örgütler sayılmadıkları için, partilerle yasal ilişki ve işbirliği söz konusu değildi. Ancak, MSP, RP ve 
AKP bu işbirliğini informal olarak sadece yerel düzeyde değil, lider düzeyinde bile yürütmüştür. ${ }^{9}$

Seçmene ve üyeye menfaat sağlama her iki modelde de görülmekle birlikte, özellikle informal modelde öne çıkmaktadır. Buna karşılık seçmen sorunlarını saptama, bunları genel politikalarla bütünleştirme işlevi formal örgütlerce yerine getirilmektedir. Formal örgüt bireylerin tek tek sorunları yerine, geniş toplum kesimlerinin sorunlarının çözümüne odaklanmaktadır. Seçmenin ve üyelerin eğitimi, adayların saptanması ve seçime hazırlanması formal örgütün temel işlevleri arasındadır.

İnformal örgütün aday belirleme, politika oluşturma, üst yönetimle ilişkiler kurmadaki edilgen konumu, bu modelde parti içi demokrasinin yokluğunu ya da en azından iyi işlemediğini göstermektedir.

\section{Katılım, kurumsallaşma, liderlik ve parti içi demokrasi}

Modern devletin ayırıcı özelliklerinden biri, siyasal katılmaya dayanmasıdır. Modern devleti geleneksel devletten ayırt eden özellik, halkın, siyasete katılmasının ve siyasetten etkilenişinin genişlemiş olmasıdır. Bir toplumda, eğer toplumsal devingenlik (mobilizasyon) ve siyasal katılma oranı yüksek; siyasal örgütlenme ve kurumsallaşma derecesi düşükse, sonuçta siyasal istikrarsızlık ve düzensizlik ortaya çıkmaktadır (Huntington, 1977:5 ve 55). Bir başka deyişle, eğer siyasal kurumsallaşma, artan siyasal katılmayı karşılayacak düzeyde değilse, siyasal istikrarı sağlamak güçleşmektedir. Acemoğlu ve Robinson da yankı uyandıran çalışmalarında ekonomik, toplumsal ve siyasal gelişme için kurumların ve kurumsallaşmanın önemini vurgulamaktadırlar (2014:79-83, 420-421). Gelişmekte olan ülkelerde siyasal yapının temel unsurlarının yeterli düzeyde kurumsallaşamaması, o ülkelerde çoğulcu demokrasinin sürekliliğini, düzenli ve verimli işlemesini engellemektedir. Türkiye bu açıdan talihsiz bir ülkedir. Türkiye'de, yaşanan askeri müdahaleler devletin tüm kurumlarını etkilemiş ve onların kurumsallaşmalarını önlemiştir (Kabasakal, 2016:221-251).

Çağdaş demokrasilerde başlıca siyasal kurumlar, yasama, yürütme ve yarg1 organları yanında siyasal partilerdir. Siyasal partiler, hemen hemen bütün ülkelerde siyasal hayatın temel unsurları ve başlıca dinamik güçleri haline gelmişlerdir. Hangi siyasal sistem içinde -demokratik, otoriter veya totaliteryer alırlarsa alsınlar, çağdaş toplumların vazgeçilmez öğeleri olarak kabul edilmektedirler (Kapani, 2005:159). Gerçekten de günümüzde partisiz rejimler, ancak siyasal modernleşmenin sağlanmadığı geleneksel toplumlarda görülebilmektedir. Siyasal partilerin, demokratik sistemlerdeki rolü özellikle önemlidir. Çünkü bu ülkelerde demokrasinin sağlıklı işlemesi, siyasal

${ }_{9}^{9}$ http:/ / www.hurriyet.com.tr/tarikat-iftari-bardagi-tasirdi-39260952 (erişim. 13.6.2019) 
partilerin kendi içlerinde de demokratik bir iç düzene ve verimli bir işleyişe sahip olmaların gerektirmektedir.

Siyasal partilerin böyle bir iç düzen kurabilmelerinin ilk koşulu, üye iradesinin aşağıdan yukarıya doğru oluşmasını sağlayacak bir örgütlenmenin oluşturulmasıdır. Bunun için, üyelerin örgütteki tüm çalışmalara ve seçimlere eşitçe katılabilme olanaklarının bulunması; yönetim organlarının belirli sürelerle merkezin müdahalesi olmaksızın düzenli olarak yenilenmesi ve partinin otoriter bir yönetime meydan vermeksizin üyelerce etkin denetimi gerekmektedir (Kabasakal, 2014). Bu ise gerek üyelerin gerek yerel örgütlerin daha etkin olmalarıyla sağlanabilir. Ancak, bu koşulların yasalarda ve tüzüklerde yer alması, uygulamada parti içinde demokratik bir işleyişi otomatik olarak sağlamaya yetmez. Çünkü yasa ve tüzüklerdeki kurallar1 uygulamak durumunda bulunan insanlar, her şeyden önce kendi kültürlerinin etkisi altında kalırlar. Partilerin örgütsel özellikleri, onların kökenlerini, gelişmelerini ve içinde bulundukları toplumsal-siyasal çerçeveyi yansıtır. $\mathrm{Bu}$ çerçevenin temeli ise o toplumun kültürüdür. Ancak, toplumsal kurumlara biçim ve yön veren ulusal kültür de toplumsal gelişmeye koşut olarak zaman içinde değişir. Yani bu konuda iki yönlü bir etkileşim söz konusudur.

Demokratik ilkeler, liderliğin, parti örgütünün her düzeyinde seçimli olmasını, sık sık yenilenmesini, kolektif nitelik taşımasını ve sınırlı bir otoriteye sahip bulunmasını gerektirir. Ancak, gerek liderlerin doğal olarak iktidarlarını koruma ve artırma eğiliminde olmaları gerek üyelerin bu eğilimi engellemek şöyle dursun, tersine liderleri putlaştırmak suretiyle onu büsbütün güçlendirmeleri bu ilkelerin işlemesini önler (Duverger, 1974:189190; Kabasakal, 2014:700-711).

Türkiye'de de parti örgütlenmesi, hiyerarşik otoriteye dayanan bir düzen içinde işlemiştir. Ayrıca, yerleşik siyasal kültür ve yasal düzenlemeler parti içi demokrasiyi geliştirmek açısından özendirici olmamıştır. Bu yüzden de siyasal partilerimiz, ekonomik ve toplumsal gelişmeye koşut olarak siyasal katılmayı, çoğulcu demokratik düzen içinde ve rejimi güçlendirecek biçimde yönlendirebilme olanağını büyük ölçüde yitirmişlerdir (Sunar, 2010:37-41). Ayrıca, toplumda her şeyi yukarıdan bekleme düşünce ve eğilimi yerleşmiş ve kökleşmiştir. Bu siyasal kültür, parti liderleri ve merkez organlarının, partinin genel politika ve stratejileriyle ilgili önemli kararlarının belirlenmesini kolaylaştırmıştır.

Yerel liderler, ulusal parti liderlerine sağladıkları destek karşıllığında onlardan kollanmalarını, maddi çıkar sağlanmasını veya özel ayrıcalıklar tanınmasını vb. beklemektedirler. Ancak, yerel örgütler güçlüyse, partiyi etkilemenin ötesinde milletvekillerini ve parti merkez yönetimini güçleri oranında yönlendirirler de (Tavits, 2013:131). Türkiye'de yerel parti örgütlerinin, siyasal yaşamda etkinlik kazandığı dönem, özellikle Demokrat Partinin iktidar yıllarıdır. Fakat bu dönemde yerel parti örgütlerinin kendi 
çevrelerinde önemli rol oynasalar bile, parti siyasetinin yönlendirilmesinde genellikle merkez organlarının öncülüğüne bağlı kaldıkları görülmüsstür.

Türkiye'deki siyasal yapı, yıllar içinde karşılaştırılarak incelendiğinde, yerel örgütlerin, yalnızca yerel düzeyde değil, göreli olarak aynı zamanda ulusal düzeyde de güç ve etkinlik kazandıkları dönemler vardır. F.W. Frey'in 19201960 yilları arasında parlamento üyeliği yapmış kişiler üzerine çalışması (Turkish Political Elite) bunu doğrulamakta ve milletvekillerinin birçoğunun yerel parti örgütlerinden geldiğini göstermektedir (1965).

İllerin coğrafi konumu, büyüklükleri, ekonomik ve toplumsal gelişme düzeyleri, aynı partinin çeşitli illerdeki örgütlerinin, yap1 ve etkinlik açısından farklılaşmasına neden olabilir. 1950’li yıllarda Türkiye'de Doğu Anadolu'daki büyük ölçüde toplumsal yap1 üzerine oturan parti örgütlenmesi buna en güzel örneklerden biridir. Büyük toprak sahipleri, aşiret reisleri ve dinsel liderler seçimlerde partilere önemli destek sağlamaktaydılar (Demirel, 2016:108). Bu desteğin ne denli başarıyla yönlendirildiği Doğu ve Güneydoğu Anadolu'nun kırsal kesimlerinde ve özellikle köy düzeyinde en iyi biçimde gözlenebilir. Bu yöreler, günümüzde bile "güdümlü" siyasal katılmanın örneklerini vermektedirler.

\section{Sonuç}

Siyasal partilerin, demokratik sistemlerdeki rolü özellikle önemlidir. Çünkü bu ülkelerde demokrasinin sağlıklı işlemesi, siyasal partilerin kendi içlerinde de, merkez taşra örgütleri arasında da demokratik bir iç düzene sahip olmalarını gerektirmektedir. Türkiye'de yerel düzeyde ilki, 1946-60 arasinda formal diğeri 1970'lerden günümüze kadar informal olmak üzere iki farklı örgütlenme modeli uygulanmıştır. İncelemeler göstermiştir ki, ocakbucak örgütlenmesi, yurttaşlarla parti ve ülke yönetimi arasında sağlıklı bir iletişim kanalı olmanın ötesinde, halkın siyasal eğitimine katkıda bulunmakta, bilinçli siyasal katılmayı artırmakta, parti içi demokrasinin daha iyi işlemesini sağlamaktaydı. Bu kurumlar asıl işlevlerini çok partili yaşamda yerine getirmişlerdir.

1960'da ocak-bucak örgütlerinin kaldırılması, ülke siyasal yaşamında önemli bir boşluk doğurmuştur. Siyasal kutuplaşmayı köy ve mahalle düzeyinde yaygınlaştırdığı ve artırdığı ileri sürülen bu kurumların, söz konusu gelişmelerin tek ve ana nedeni olmadığ1, 27 Mayıs 1960 ile 12 Eylül 1980 tarihleri arasındaki siyasal olaylarla kanıtlanmıştır. Ocak-bucak örgütlerinin bulunmadığ1 bu dönemde, Türk siyasal yaşamı, belki de tarihinin en yoğun kutuplaşma ve cepheleşme hareketlerine sahne olmuştur. Özellikle 19751980 yilları arasında, kahveler ve camiler değil, mahalleler, hatta şehirler ayrılmıştır. Oysa bu sırada partiler, mahalle ve köylerde örgüt açmaktan yoksundular. Partilerin ocak ve bucak örgütleri çalışmaya devam etseydi, belki de Türkiye, bu denli yoğun ve kanlı bir kutuplaşmayı yaşamayacaktı. 
Günümüzde de ocak bucak örgütleri bulunmadığı halde, toplumdaki siyasal kutuplaşmanın Cumhuriyet tarihinin hiç görmediği düzeye ulaştığı sıkça ileri sürülmektedir.

1965'e kadar Türkiye'de partiler, Dernekler Kanununa göre örgütlendikleri için tek tip bir örgütlenme modeli yoktu. Bu yüzden partiler farklı örgütlenme modelleri uygulayabilirlerdi. Türkiye'de parti örgütlenmesi, 1960 öncesinde genel olarak idari bölünmeye uygunluk göstermiş, özellikle 1960'dan sonra, Devletin idari örgütlenmesiyle tamamen çakışmıştır. 1960'da partilerin ilçe düzeyinin altındaki örgütlerinin kaldırılmasından sonra, 1965 tarihli Siyasal Partiler Kanunu tek-tip örgütlenmeyi zorunlu kilmıştır. 1980 darbesinden sonra 1983'te çıarılan 2820 Saylı Siyasi Partiler Kanunu da aynı kuralları benimsemiştir.

1961 ve 1982 Anayasaları doğrultusunda çıkarılan siyasal partiler yasaları da halkın siyasete katılmasını sınırlamıştır. Oysa genç nüfusun çoğunluğu oluşturduğu Türk toplumu, dinamik bir yapı göstermektedir. Bazı partiler bu yapıya uygun küçük yerel birimlere dayalı modeller geliştirseler bile bunları hayata geçirememişlerdir (Erdem, 2001:93-77).

Bu çalışa, Tablo.1'de özetlendiği gibi, Türkiye'de 1960'a kadar varllğını sürdüren formal ocak ve bucak örgütleri ile 1970'lerden itibaren MSP, RP ve AKP'de görülen informal yerel örgütlenmenin partilerinin yerel düzeyde güçlenmesine katkı sağladığını göstermektedir. Ancak, araştırmalar 1970 sonrası MSP, RP ve AKP'de görülen informal yerel örgütlenmenin merkez organlarına bağımlı işlediğini ve parti içi demokrasiye önemli bir katkı yapamadığını ortaya koymaktadır.

Türkiye'de demokrasinin pekişmesi, başka alanlarda olduğu gibi, siyasal partilerde de demokratik işleyişin yerleşmesine bağlıdır. Bu ise parti içi demokrasinin gelişmesini, üyenin ve yerel örgütlerin kararlara ve süreçlere daha aktif katılmasını zorunlu kılmaktadır. 1946'dan beri çok partili siyasal yaşamı -ara sıra kesintilere uğrasa da- sürdürmeye çalışan Türkiye, evrensel değerlere sahip bir toplum hedefine ulaşmak için, ekonomik ve toplumsal alanda gösterilecek çabalar yanında; siyasal alanda da çă̆ın gerektirdiği kapsayıcı siyasal kurumları oluşturmak ve kurumsallaşmayı etkin ve yaygın bir siyasal parti örgütlenmesiyle sağlamak zorundadır. 


\section{Kaynakça}

Acemoğlu, D. ve Robinson, J. A. (2014). Uluslarn Düşüsü. 7. Bask1, Doğan Kitap, İstanbul.

Aldrich, J. H. (2000). "Southern Parties in State and Nation". Journal of Politics, 62(3): 643-670.

Almond, G. A. ve Vebra, S. (1963). The Civic Culture, Political Attitudes and Democracy in Five Nations. Princeton University Press, Princeton, New Jersey.

Appleton, A. W. ve Ward, D. S. (1997). "Party Response to Environmental Change: A Model of Organizational Innovation". Party Politics, 3(3): 341-362.

Aslan-Akman, C. (2012). "Democratic Consolidation and Institutional Challenges for Political Parties and the Party Systems in Turkey", Democratic Consolidation in Turkey. M. Aknur (drl.). Universal Publishers, Boca Raton.

Barnes, S. H. (1971). "Democracy and the Organization of Political Parties: Some Speculations". Comparative Study of Party Organization. W.E. Wright (drl.). Charles E. Merrill Publishing Company, Columbus, Ohio.

Beck, P. ve Heidemann, E. (2014). "Changing Strategies in Grassroots Canvassing: 1956-2012”. Party Politics, 20(2): 261-274.

Bosuter, K. (1969). Türk Siyasi Partiler Sisteminde Parti Ị̇i Demokrasi. Ulusal Basımevi, Ankara.

Bursalı, O. (2018). "Yoksulluğu ve yeni orta sınıfı başarılyla yönetmek". Seçim analizi-3, Cumburiyet, 1 Temmuz 2018.

CHP'de Islahat Yapılması Ị̇in Teklif. (1950). Partinin VIII ci Büyük Kurultayı münasebetiyle ve Kurultaya sunulmak üzere hazırlatılmıştır. (39 sayfa).Türkiye Matbaacılık ve Gazetecilik A.O., Yeni Matbaa, Ankara.

Clark, A. (2004). "The Continued Relevance of Local Parties in Representative Democracies". Politics, 24 (1): 35-45.

Cotter, C. P. vd. (1984). Party Organizations in American Politics. Praeger, New York.

Dalton, R. J., Farrell, D. M. ve McAllister, I. (2011). "The dynamics of political representation", How Democracy Works: Political Representation and Policy Congruence in Modern Societies. M. Rosema, B. Denters ve K. Aarts (drl.), University of Chicago Press, Chicago. 
Demirel, T. (2016). Türkiye'nin Uzun On Yll, Demokrat Parti İktidarı ve 27 Mayıs Darbesi. 2. Baskı. İ. Bilgi Üniversitesi Yayınları, İstanbul.

Diler, N. (1964). Millet Meclisi Tutanak Dergisi, 30 Ocak 1964.

Doğan, S. (2017). Mahalledeki AKP: Parti İsleyişi, Taban Mobilizasyonu ve Siyasal Yabancılaşma. İletişim Yayınları, İstanbul.

Duverger, M. (1974). Siyasi Partiler. (Çev. E Özbudun), 2. Bask1, Bilgi Yayınevi, Ankara.

Ecevit, B. (1960a). “Ocak Bucak”, Ulus, 5 Temmuz 1960.

Ecevit, B. (1960b). "Politikasız Demokrasi”, Ulus, 7 Temmuz 1960.

Ecevit, B. (1976). Ecevit’in Açklamaları 1976. Ajans-Türk Matbaası, Ankara.

Ecevit, B. (1981). “Ocağ1 Söndürülen Demokrasi”, Arayış Dergisi, (12): 4-7.

Erdem, T. (2001). Tikanan Siyaset. Sel Yayıncilık, İstanbul.

Frendreis, J. P., Gibson, J. L. ve Vertz, L. L. (1990). “'The Electoral Relevance of Local Party Organizations". American Political Science Review, 84(1): 225-235.

Frendreis, J. P. (1993). "Local Parties in an Age of Change". American Review of Politics, (14): 533-547.

Frendreis, J. P. ve Alan, R. G. (1999). "Local Parties in the 1990s: Spokes in a Candidate-Centered Wheel". The State of the Parties: The Changing Role of Contemporary American Parties. J. C. Green ve D. M. Shea (drl.), 3. Bask1, Rowman \& Littlefield, Lanham.

Frey, F. W. (1965). The Turkish Political Elite. The MIT (Massachusetts Institute of Technology) Press, Cambridge.

Gibson, J. L. vd. (1989). "Party Dynamics in 1980s, Change in County Party Organizational Strength, 1980-84". American Journal of Political Science, (33): 67-90.

Hazan, R. Y. ve Rahat, G. (2010). Democracy within Parties: Candidate Selection Methods and their Consequences. Oxford University Press, Oxford.

Herrnson, P. S. (2002). "National Party Organizations at the Dawn of the Twenty-First Century". The Parties Respond: Changes in American Parties and Campaigns. 4. Bask1, Boulder, CO, Westview.

Huntington, S. P. (1977). Political Order in Changing Societies. 13. Basim, Yale University Press, New Haven.

Kabasakal, M. (1991). Türkiye’de Siyasal Parti Örgütlenmesi 1908-1960. Tekin Yayınevi, İstanbul. 
Kabasakal, M. (1995). “ Türkiye'de Siyasal Parti Örgütlenmesindeki Kisttlamalar". Siyasi Partiler ve Demokrasi. Sempozyum, TESAV Yayınları, Ankara.

Kabasakal, M. (2014). "Factors influencing intra-party democracy and membership rights: The case of Turkey". Party Politics, 20 (5): 700711.

Kabasakal, M. (2016). “Türkiye'de Siyasal Partiler”, Türkiye’de Siyasal Yaşam, Dün Bugün Yarn. Mehmet Kabasakal (drl.), İstanbul Bilgi Üniversitesi Yayınları, İstanbul.

Kapani, M. (2005). Politika Bilimine Giriş, 17. Basım, Bilgi Yayınevi, Ankara.

Kirca, C. (1965). Millet Meclisi Tutanak Dergisi, B. 74,18.3.1965: 357-359.

Neftçi, N. (1997). Demokrasinin Kilittaşı, Amılar. TESAV Yayınları 14. Işık Matbaacilik, Ankara.

Oğuz, T, (1965). Millet Meclisi Tutanak Dergisi, B. 74,12.3.1965: 364.

Özbudun, E. (1975). Türkijye'de Sosyal Değğsme ve Siyasal Katılma, A.Ü. Hukuk Fakültesi Yayınlanı: 363, Sevinç Matbaası, Ankara.

Özbudun, E. (1979). Siyasal Partiler, Üçüncü Bas1, A.Ü. Hukuk Fakültesi Yayınları, Ankara.

Özbudun, E. ve Hale, W. (2010). Türkiye'de İslamcllk, Demokrasi ve Liberalizm: AKP Olayı. Doğan Kitap, İstanbul.

Roscoe, D. D. ve Jenkins, S. (2014). "Changes in Local Party Structure and Activity, 1980-2008", The State of the Parties: The Changing Role of Contemporary American Parties. 7. Bask1, J. C. Green, D. J. Coffey ve D. Cohen (drl.), Rowman \& Littlefield, Lanham.

Roscoe, D. D. ve Jenkins, S. (2016). Local Party Organizations in the TwentyFirst Century. State University of New York Press, Albany.

Sartori, G. (1977). Parties and party systems: A framework. for analysis. Cambridge University Press, Cambridge.

Soysal, M. (1982). “Ocak ve Bucak”, Milliyet, 8 Aralık 1982.

Sunar, İ. (2010). Demokrasi, Türkiye Serüveni. Doruk Yayımc1lı, İstanbul.

Szyliowicz, J. S. (1966). Political Change in Rural Turkey Erdemli. Mouton and Co. The Hague, Paris.

Tavits, M. (2013). Post-Communist Democracies and Party Organization, Cambridge University Press, New York. 
Teziç, E. (1976). Siyasi Partiler, Partilerin Hukuki Rejimi ve Türkiye'de Partiler. Gerçek Yayınevi, İstanbul.

Topuz, A. (2011). Ali Topuz. Anlatıyor-1: Değişimi Yaşamak (1932-1972). Doğan Kitap, İstanbul.

Tunaya, T. Z. (1952). Türkiye'de Siyasi Partiler, 1859-1952. Doğan Kardeş Yayınları, İstanbul.

Tuncay, S. (2000). Parti İci Demokrasi. Gündoğan Yayınları, İstanbul.

Wright, W. E. (1971). "Comparative Party Models: Rational-Efficient and Party Democracy". Comparative Study of Party Organization. W. E. Wright (drl.), Charles E. Merrill Publishing Company, Columbus, Ohio. 